This is the peer reviewed version of the following article: G. Yassaghi, E. Andris, J. Roithová, ChemPhysChem 2017, 18, 2217, which has been published in final form at http://onlinelibrary.wiley.com/doi/10.1002/cphc.201700490/full. This article may be used for non-commercial purposes in accordance with Wiley Terms and Conditions for SelfArchiving. 


\title{
Reactivity of copper(III)-oxo complexes in the gas phase
}

\author{
Ghazaleh Yassaghi, Erik Andris and Jana Roithová*
}

\begin{abstract}
:
We show an efficient way to generate $[(\mathrm{L}) \mathrm{CuO}]^{+}$complexes with a number of monodentate and bidentate ligands $L$ from their $\left[(\mathrm{L}) \mathrm{Cu}\left(\mathrm{ClO}_{3}\right)\right]^{+}$precursors by electrospray ionization. Further, we studied $[(\mathrm{L}) \mathrm{CuO}]^{+}$with $\mathrm{L}=9,10$-phenanthraquinone, 1,10phenanthroline and acetonitrile in detail. The signature of these terminal copper-oxo complexes is elimination of the oxygen atom upon collisional activation. We have investigated and
\end{abstract}

\section{Introduction}

Hypervalent metal-oxo complexes attract attention of many chemists because of their high reactivity. ${ }^{[1-5]}$ Most importantly, these complexes are capable of mediating $\mathrm{C}-\mathrm{H}$ activations or act as oxygen transfer reagents. ${ }^{[6,7]}$ Another interesting field is water oxidation and several potential catalysts based on a metal-oxo moiety have been investigated. ${ }^{[8-13]}$

The reactivity of the terminal metal-oxo complexes is largely influenced by the metal involved and many fundamental studies have been devoted to this topic. ${ }^{[14,15]}$ Most of the catalysts developed on these grounds are based on iron(IV)-oxo motif, but studies exist for almost all $3 d$ metals $^{[15,16]}$ - the resisting metal being copper. Theoretical as well as the gas phase studies predict a particularly high reactivity of the copper(III)-oxo complexes due to a small Cu-O binding energy ${ }^{[17-19]}$ and the predicted single-state reactivity in reactions with hydrocarbons. ${ }^{[14,20]}$ Potent reactivity is also expected based on numerous enzymes that use one or more copper centers in oxidation reactions (e.g. copper monooxygenase, multicopper oxidases, particulate methane monooxygenase). ${ }^{[21-23]}$

Copper(III) intermediates are predicted to play an important role in many copper-catalyzed reactions. ${ }^{[24]}$ Many reaction mechanisms are rationalized based on theory, because experimental detection of neutral or positively charged copper(III) intermediates is challenging. Stable copper(III) complexes prepared so far rely on highly stabilizing planar tetradentate ligands. ${ }^{[25-30]}$ Recent years also brought a success in the field of investigation of negatively charged Gilman cuprates. ${ }^{[31,32]}$ As far as the application of copper(III) complexes for oxidation catalysis is concerned, Tolman and coworkers

[*] G. Yassaghi, E. Andris, Prof. J. Roithová Department of Organic Chemistry,

Faculty of Science, Charles University

Hlavova 2030/8, 12843 Prague 2 (Czech Republic)

E-mail: roithova@natur.cuni.cz

Supporting information for this article is given via a link at the end of the document. compared their reactions with water, ethane, ethylene and 1,4cyclohexadiene. The $\left[\left(\mathrm{CH}_{3} \mathrm{CN}\right) \mathrm{CuO}\right]^{+}$complex can oxidize water and perform $\mathrm{C}-\mathrm{H}$ activation and hydroxylation of ethane. The complexes with bidentate ligands do not react with water and can oxidize only larger hydrocarbons. All the investigated complexes show comparable reactivity in the oxygen transfer reaction with ethylene.

developed an approach based on electrochemical oxidation of a $\left[(\mathrm{L}-2 \mathrm{H}) \mathrm{Cu}^{\mathrm{II}}-\mathrm{OH}\right]^{-}$complex, where $(\mathrm{L}-2 \mathrm{H})$ is a bis-deprotonated pincer ligand. ${ }^{[33]}$ The generated $\left[(\mathrm{L}-2 \mathrm{H}) \mathrm{Cu} \mathrm{u}^{\mathrm{III}}-\mathrm{OH}\right]$ complexes activate $\mathrm{C}-\mathrm{H}$ bonds. ${ }^{[34]}$ Another important group of copper(III) species belongs among dinuclear $\mu$-oxo complexes. ${ }^{[35-38]}$

Schwarz and coworkers were able to generate bare $\mathrm{CuO}^{+}$ ions in the gas phase and show their reactivity with methane. ${ }^{[20]}$ Another system studied in the gas phase is the [(phen)CuO $]^{+}$ complex (phen = 1,10-phenanthroline). The $\left[(\right.$ phen $) \mathrm{CuO}^{+}$ cations can be generated as a mixture of the reactive $\left[(\text { phen }) \mathrm{Cu}^{\text {IIII}}-\mathrm{O}\right]^{+}$ions and isomers with an oxidized ligand, $\left[\left(\text { phen }^{\text {ox }}\right) \mathrm{Cu}^{\prime}\right]^{+}$(see Scheme 1). ${ }^{[39,40]}$ The phenanthroline ligand suppresses the reactivity of the $[\mathrm{Cu}-\mathrm{O}]^{+}$core compared to the bare ion: The activation of methane is not possible, but fluoromethanes or alkanes starting with propane readily undergo the desired $\mathrm{C}-\mathrm{H}$ activation. ${ }^{[39,41]}$ The high reactivity of the $\left[(\text { phen }) \mathrm{Cu}^{\text {III }}-\mathrm{O}\right]^{+}$complex is also reflected by its self-oxidation, which leads to the hydroxylation of the ligand and the formation of the $\left[\left(\text { phen }^{\text {ox }}\right) \mathrm{Cu}^{l}\right]^{+}$isomer. ${ }^{[40]}$

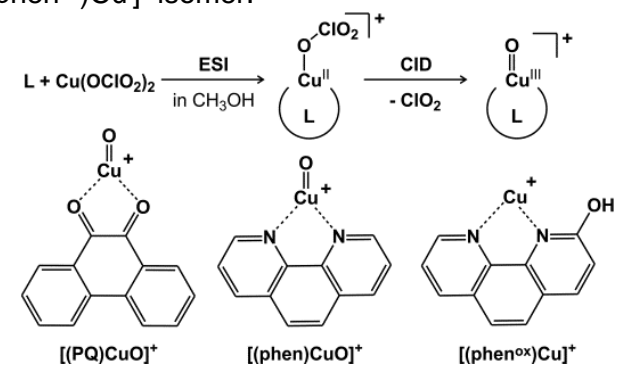

Scheme 1. Generation of the $[(\mathrm{L}) \mathrm{CuO}]^{+}$complexes $(L=P Q$, phen, acetonitrile acetone, methanol, tetrahydrofurane and $N, N$-dimethylformamide) by insource fragmentation during electrospray ionization and structures of the generated complexes.

Here, we will show an approach to generate new copper(III)-oxo complexes and we will compare their reactivity in $\mathrm{C}-\mathrm{H}$ activation reactions, oxygen transfer reactions, and water oxidation reactions. 


\section{Results and Discussion}

2.1. Generation of the $[(\mathrm{L}) \mathrm{CuO}]^{+}$ions. The previously reported $\left[(\text { phen }) \mathrm{Cu}^{\text {III }-}-\mathrm{O}\right]^{+}$ions were generated from the $\left[(\text {phen }) \mathrm{Cu}^{\prime \prime}\left(\mathrm{NO}_{3}\right)\right]^{+}$ precursors by their collisional induced dissociation (CID). ${ }^{[39-41]}$ The $\mathrm{NO}_{2}{ }^{\cdot}$ elimination, leading to the required $\left[(\mathrm{L}) \mathrm{Cu}^{\prime \prime \prime}-\mathrm{O}\right]^{+}$ions, is a minor channel. The competing fragmentation is the loss of the $\mathrm{NO}_{3} \cdot$ radical. We wanted to increase the yield of the $\left[(\mathrm{L}) \mathrm{Cu}^{\mathrm{III}}-\mathrm{O}\right]^{+}$ product ions and therefore we tested chlorate and perchlorate as counter ions in the fragmentation reaction. We performed the test experiments with complexes bearing 9,10phenanthraquinone $(\mathrm{PQ})$ ligand. The $[(\mathrm{PQ}) \mathrm{Cu}(\mathrm{X})]^{+}$complexes were generated from methanolic solutions of $P Q$ and the corresponding $\mathrm{CuX}_{2}$ salt $\left(\mathrm{X}=\mathrm{NO}_{3}, \mathrm{ClO}_{4}\right.$ and $\left.\mathrm{ClO}_{3}\right)$ by electrospray ionization. Comparison of the CID experiments with mass-selected $\quad\left[(\mathrm{PQ}) \mathrm{Cu}\left(\mathrm{NO}_{3}\right)\right]^{+}, \quad\left[(\mathrm{PQ}) \mathrm{Cu}\left(\mathrm{ClO}_{4}\right)\right]^{+} \quad$ and $\left[(\mathrm{PQ}) \mathrm{Cu}\left(\mathrm{ClO}_{3}\right)\right]^{+}$clearly shows that the use of chlorate counter ion is superior to the other alternatives (Figure 1).

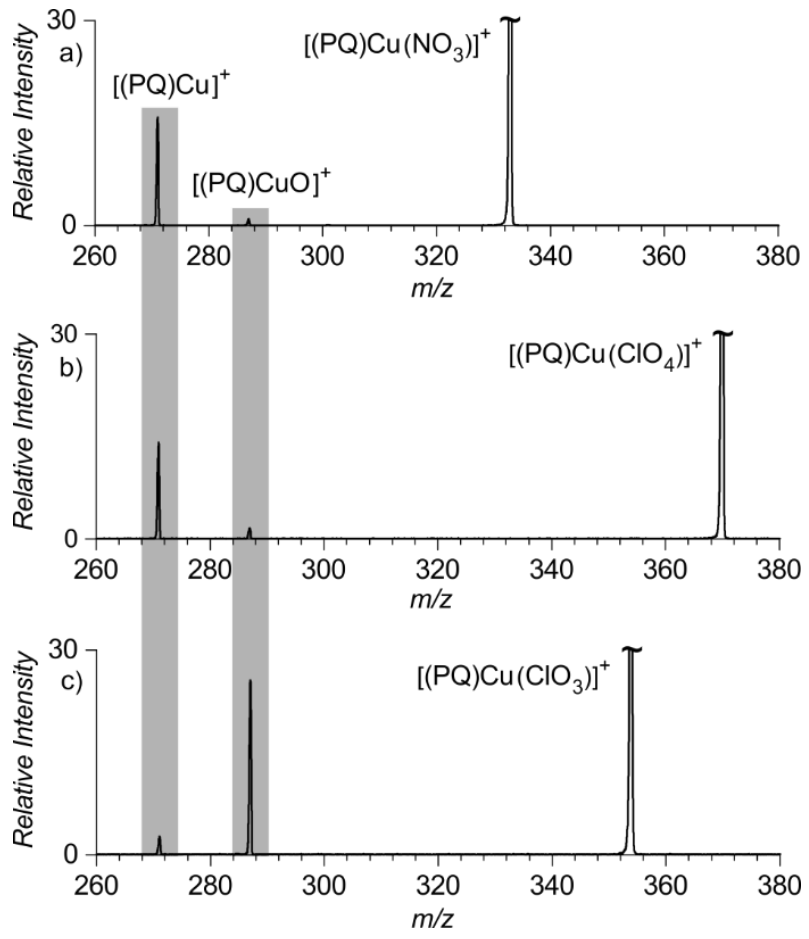

Figure 1. CID spectra of mass-selected a) $\left[(\mathrm{PQ}) \mathrm{Cu}\left(\mathrm{NO}_{3}\right)\right]^{+}(\mathrm{m} / z$ 333), b) $\left[(\mathrm{PQ}) \mathrm{Cu}\left(\mathrm{ClO}_{4}\right)\right]^{+}(\mathrm{m} / z 370)$ and $\left.c\right)\left[(\mathrm{PQ}) \mathrm{Cu}\left(\mathrm{ClO}_{3}\right)\right]^{+}(\mathrm{m} / \mathrm{z} 354)$. Collision gas: Xe; pressure: $0.2 \mathrm{mTorr}$; collision energy $5 \mathrm{eV}$ (center-of-mass frame); the parent ion peaks were normalized to 100 .

For further experiments, the hypervalent copper(III)-oxo complexes were generated by CID in the ion source. It means that the ions are generated by electrospray ionization in the usual way, but the transfer ion optics (lenses, capillary) are set to a high potential difference. The generated ions are thus accelerated in the ion-source region and undergo collisions with nitrogen (used as a sheath gas). The fragmentation requires energetic collisions and therefore the internal energy distribution of the generated ions corresponds probably to a higher temperature than the room temperature. The use of copper(II) chlorate enabled us to generate a series of $[(\mathrm{L}) \mathrm{CuO}]^{+}$complexes with $\mathrm{L}=\mathrm{PQ}$, phen, acetonitrile, acetone, methanol, tetrahydrofurane and $\mathrm{N}, \mathrm{N}$-dimethylformamide.

The copper(III)-oxo complexes have a characteristic CID pattern: The weak $\mathrm{Cu}-\mathrm{O}$ bond easily cleaves and the oxygen atom is eliminated. Figure 2 shows such CID patterns for the $\left[\left(\mathrm{CH}_{3} \mathrm{CN}\right) \mathrm{CuO}\right]^{+}$and $[(\mathrm{PQ}) \mathrm{CuO}]^{+}$complexes; the CID spectra of the remaining complexes can be found in the Supporting Information (Figures S4a-d). The dominant fragment in the CID spectra of most of the $\left[(\mathrm{L}) \mathrm{CuO}^{+}\right.$complexes is $[(\mathrm{L}) \mathrm{Cu}]^{+}$. The oxygen elimination can compete with the elimination of the ligand $\mathrm{L}$. This channel is efficient only for monodentate ligands $\mathrm{L}$ (e.g. acetonitrile, Figure $2 \mathrm{a}$ ). In the $\mathrm{CID}$ spectrum of $\left[(\mathrm{PQ}) \mathrm{CuO}^{+}\right.$, the weak competing channel most probably corresponds to decarbonylation of the ligand and formation of [(PQ-CO)CuO $]^{+}$ (Figure 2b). Decarbonylation can be a sign of hydroxylated aromatic ring. In the CID spectrum of the [(phen)CuO $]^{+}$complex, decarbonylation is the dominant channel. It is due to the isobaric impurity of the $\left[\left(\text { phen }^{\mathrm{ox}}\right) \mathrm{Cu}\right]^{+}$ions (see Scheme 1) that undergoes decarbonylation of the hydroxylated aromatic ring (Figure S3).
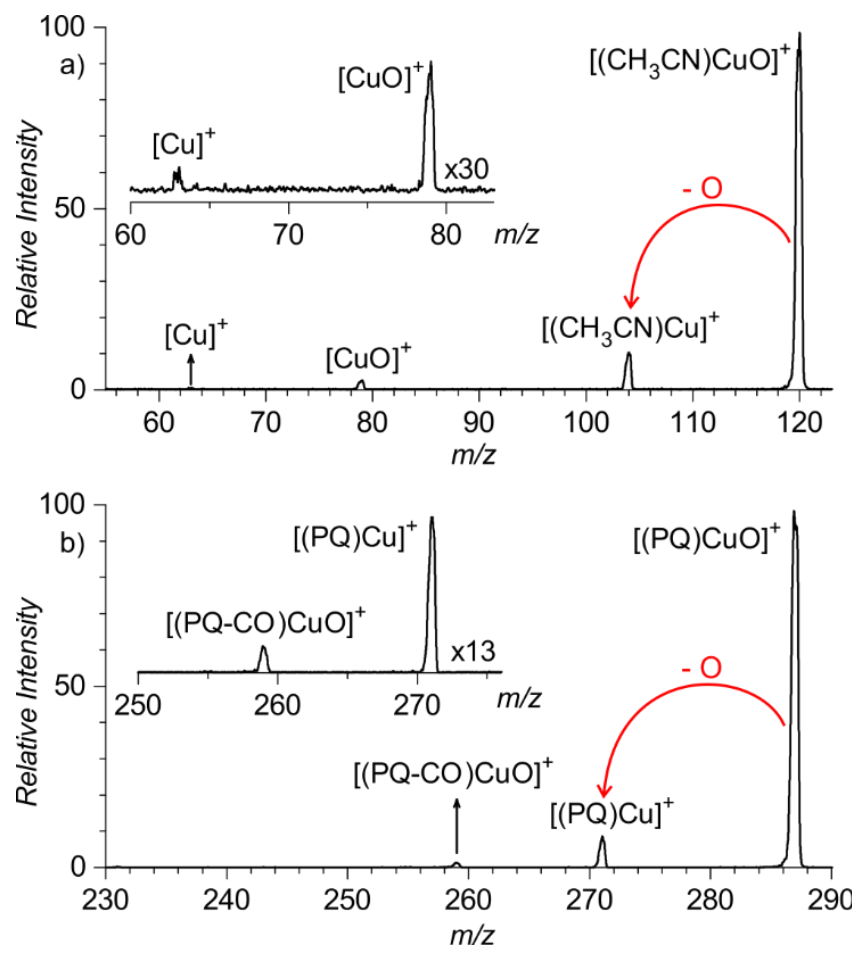

Figure 2. CID spectra of mass-selected a) $\left[\left(\mathrm{CH}_{3} \mathrm{CN}\right) \mathrm{CuO}\right]^{+}(\mathrm{m} / \mathrm{z} 120)$ and $\left.\mathrm{b}\right)$ $[(\mathrm{PQ}) \mathrm{CuO}]^{+}(\mathrm{m} / \mathrm{z} 287)$ with the dominant loss of the oxygen atom. Collision gas: Xe; pressure: 0.2 mTorr; collision energy: $10 \mathrm{eV}$ for $\left[\left(\mathrm{CH}_{3} \mathrm{CN}\right) \mathrm{CuO}\right]^{+}$and 6 $\mathrm{eV}$ for $[(\mathrm{PQ}) \mathrm{CuO}]^{+}$(both in the center-of-mass frame).

2.2. Structure of the $[(P Q) C u O]^{+}$ions. Previous investigation of the reactivity of ligated copper(III)-oxo complexes in the gas phase was done with the $[(\text { phen }) \mathrm{CuO}]^{+}$complex. It can be understood as a "benchmark" complex in the field, but it has a serious pitfall too. It is always generated together with the isomeric ions $\left[\left(p^{\circ e n}{ }^{o x}\right) \mathrm{Cu}\right]^{+}($Scheme 1$)$. Genuine reactivity of the $[(\text { phen }) \mathrm{CuO}]^{+}$complex can be studied only if the $\left[\left(\text {phen }^{\mathrm{ox}}\right) \mathrm{Cu}\right]^{+}$ isomers are separated out by the ion mobility technique. ${ }^{[47,41]}$ 
The phenanthroline ligand is oxidized during the generation of the $\left[(\right.$ phen $) \mathrm{CuO}^{+}$complex by a self-oxidation mechanism. ${ }^{[40]}$ The copper-bound oxygen atom abstracts a hydrogen atom from the neighbouring aromatic carbon atom. In order to supress this reactivity, we have turned our attention to an alternative bidentate ligand - 9,10-phenanthraquinone. In this ligand, the closest $\mathrm{C}-\mathrm{H}$ group is much further away from the coordination site and therefore the simple self-oxidation should not be possible.

The structure of the generated $[(\mathrm{PQ}) \mathrm{CuO}]^{+}$complexes was checked by infrared multiphoton dissociation (IRMPD) spectroscopy (Figure 3). ${ }^{[42-44]}$ Comparison of the experimental spectrum and the DFT (density functional theory) calculated spectra shows a very nice agreement with the triplet state of the copper(III)-oxo complex ([(PQ)CuO $\left.]^{+}\right)$. The IR spectra of possible copper(I) isomers with oxidized ligands display a phenolic $\mathrm{C}-\mathrm{O}$ stretching vibration and $\mathrm{C}-\mathrm{O}-\mathrm{H}$ deformation vibration in the $1200-1350 \mathrm{~cm}^{-1}$ range. It is nicely visible in the theoretical spectrum of the most stable singlet-state isomer in Figure $3 \mathrm{c}$ (for other isomers see the Supporting Information, Figure S19). The same spectral features led previously to the identification of the $\left[\left(\text { phen }^{\text {ox }}\right) \mathrm{Cu}\right]^{+}$isomer (Scheme 1). ${ }^{[40]}$ This vibration is not present in the experimental spectrum of $\left[(\mathrm{PQ}) \mathrm{CuO}^{+}\right.$. We therefore conclude that the self-oxidation of the $[(\mathrm{PQ}) \mathrm{CuO}]^{+}$complex is supressed and the generated ions in majority correspond to the copper(III)-oxo complexes.

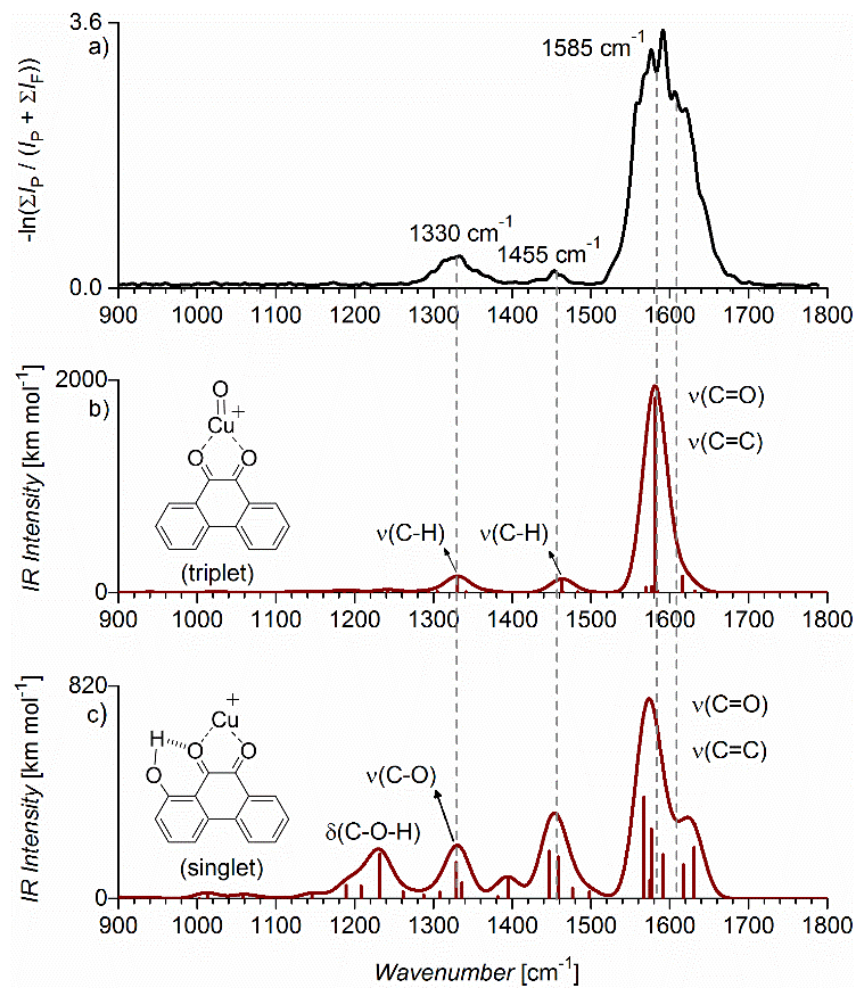

Figure 3. Comparison of a) the IRMPD spectrum of the $[(\mathrm{PQ}) \mathrm{CuO}]^{+}$complex and $b, c)$ theoretical gas phase IR spectra of selected isomers of [(PQ)CuO ${ }^{+}$ (B3LYP-D3/6-311+G*; the scaling factor was 0.986 ; the line spectra are folded with a Gaussian function with fwhm $=15 \mathrm{~cm}^{-1}$ ).
2.3. Reactivity of the $[(\mathrm{L}) \mathrm{CuO}]^{+}$ions. We have investigated properties of the copper(III)-oxo complexes in reactions with water, ethane and ethylene. We compared complexes with the monodentate ligand acetonitrile and the bidentate ligand $P Q$. Also, we measured the reactivity of the "benchmark complex" with the phen ligand keeping in mind that only part of the generated ions is reactive. The aim is a qualitative comparison of the reactions, so we investigated them at similar conditions. The ions were generated at similar ionization conditions (the identical conditions for given reactant ions). Kinetic energy distribution was typically narrower than $0.8 \mathrm{eV}$ (full width at half maximum in the laboratory frame) and the collision energy was nominally $0 \mathrm{eV}$ (Figure S5).

2.3.1. Reaction with $\mathrm{H}_{2} \mathrm{O}$. The most reactive complex is $\left[\left(\mathrm{CH}_{3} \mathrm{CN}\right) \mathrm{CuO}\right]^{+}$. The dominant channel in the reaction with water is the formation of $\mathrm{H}_{2} \mathrm{O}_{2}$ (Reaction 1). It can be observed as a loss of the oxygen atom followed by addition of another water molecule (red peaks in Figure 4, addition of water is indicated by the blue arrows). A minor reaction pathway leads to the naked $\mathrm{Cu}^{+}$ion (Reaction 2). The copper ion in the subsequent steps associates with one or two water molecules. Both reaction channels have largest cross sections at nominally zero collision energy (Figure S12).

Bimolecular reactions favoured at low collision energies are those that form a reaction (collisional) complex and that do not require an additional energy to surmount a reaction barrier or to form endothermic products. The data observed here thus mean that the reaction between $\left[\left(\mathrm{CH}_{3} \mathrm{CN}\right) \mathrm{CuO}\right]^{+}$and $\mathrm{H}_{2} \mathrm{O}$ proceeds via a collisional complex and is exothermic. Our experimental conditions enable stabilization of the collisional complex by subsequent collisions with the reactant gas in the collision cell. We can observed this effect as signals of the association products $\left(\left[\left(\mathrm{CH}_{3} \mathrm{CN}\right) \mathrm{CuO}\left(\mathrm{H}_{2} \mathrm{O}\right)\right]^{+}\right)$. The cross sections for the product formations rise linearly or sub-linearly with the increasing reactant-gas pressure (see Figures $\mathrm{S} 12$ - S18). It corroborates that the collisional complex is formed in a bimolecular reaction. Alternative mechanism for the formation of a long-lived collisional complex would involve three-body association. Such scenario should lead to a quadratic dependence of the cross section on the reactant-gas pressure.

$$
\begin{aligned}
{\left[\left(\mathrm{CH}_{3} \mathrm{CN}\right) \mathrm{CuO}^{+}+\mathrm{H}_{2} \mathrm{O} \rightarrow\right.} & {\left[\left(\mathrm{CH}_{3} \mathrm{CN}\right) \mathrm{CuO}\left(\mathrm{H}_{2} \mathrm{O}\right)\right]^{+} \rightarrow } \\
& {\left[\left(\mathrm{CH}_{3} \mathrm{CN}\right) \mathrm{Cu}\right]^{+}+\mathrm{H}_{2} \mathrm{O}_{2} } \\
{\left[\left(\mathrm{CH}_{3} \mathrm{CN}\right) \mathrm{CuO}\right]^{+}+\mathrm{H}_{2} \mathrm{O} \rightarrow } & {\left[\left(\mathrm{CH}_{3} \mathrm{CN}\right) \mathrm{CuO}\left(\mathrm{H}_{2} \mathrm{O}\right)\right]^{+} \rightarrow } \\
& \mathrm{Cu}^{+}+\left[\mathrm{CH}_{3} \mathrm{CN}, \mathrm{O}, \mathrm{H}_{2} \mathrm{O}\right]
\end{aligned}
$$




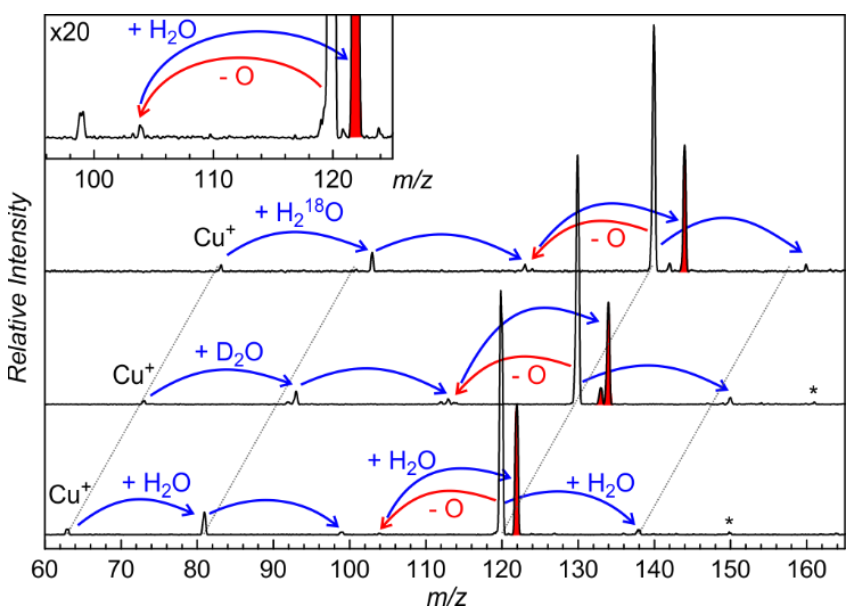

Figure 4. Reaction of mass-selected $\left[\left(\mathrm{CH}_{3} \mathrm{CN}\right) \mathrm{CuO}\right]^{+}\left(\mathrm{m} / z\right.$ 120) with $\mathrm{H}_{2} \mathrm{O}, \mathrm{D}_{2} \mathrm{O}$ and $\mathrm{H}_{2}{ }^{18} \mathrm{O}\left(E_{\text {coll }}=0 \mathrm{eV}, P\left(\mathrm{H}_{2} \mathrm{O}\right)=0.2 \mathrm{mTorr}\right)$. The star symbols refer to adducts formed with background gases.

Reactions between the $[(\mathrm{L}) \mathrm{CuO}]^{+}$complexes $(\mathrm{L}=$ phen or $P Q$ ) and water lead neither to the water oxidation nor to the production of the naked copper ion. Instead, we only see a reversible addition/elimination of water leading to the oxygen atom exchange (Reaction 3 ). It can be clearly observed in the reaction with $\mathrm{H}_{2}{ }^{18} \mathrm{O}$ that provides (contrary to the reactions with $\mathrm{H}_{2} \mathrm{O}$ or $\mathrm{D}_{2} \mathrm{O}$ ) product ions with $\Delta m / z+2$ (Figure 5 and S11-S17).

$[(\mathrm{L}) \mathrm{CuO}]^{+}+\mathrm{H}_{2}{ }^{18} \mathrm{O} \rightarrow\left[(\mathrm{L}) \mathrm{CuO}\left(\mathrm{H}_{2}{ }^{18} \mathrm{O}\right)\right]^{+} \rightarrow\left[(\mathrm{L}) \mathrm{Cu}^{18} \mathrm{O}\right]^{+}+\mathrm{H}_{2} \mathrm{O}$

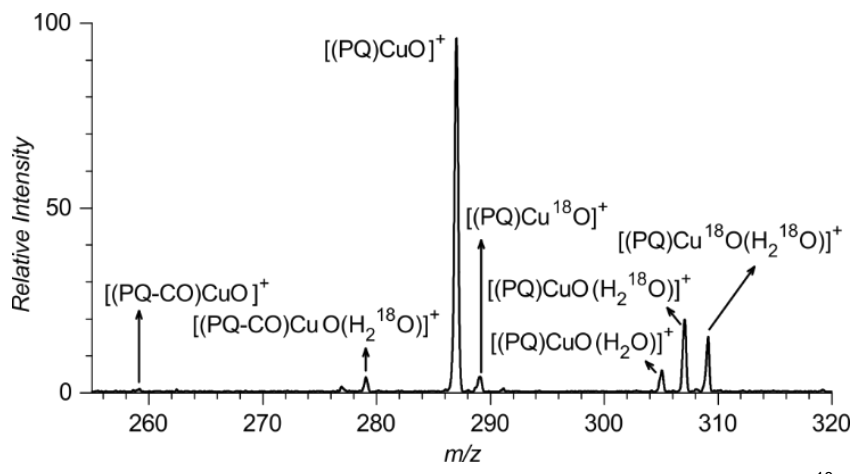

Figure 5. Reaction of the mass-selected [(PQ)CuO] ${ }^{+}$ions $(m / z 287)$ with $\mathrm{H}_{2}{ }^{18} \mathrm{O}$ $\left(E_{\mathrm{CM}}=0 \mathrm{eV}, P\left(\mathrm{H}_{2} \mathrm{O}\right)=0.2 \mathrm{mTorr}\right)$.

2.3.2. Reaction with ethane. The smallest alkane that undergoes $\mathrm{C}-\mathrm{H}$ activation with $\left[\left(\mathrm{CH}_{3} \mathrm{CN}\right) \mathrm{CuO}\right]^{+}$is ethane (Figure 6 ). It does not only abstract one hydrogen atom (Reaction 4), but it also completes the reaction by the rebound of the ethyl radical with the hydroxyl group evidenced by a formal loss of the oxygen atom (Reaction 5). We have also detected double hydrogen abstraction leading to the dehydrogenation of ethane (Reaction 6).

$\left[\left(\mathrm{CH}_{3} \mathrm{CN}\right) \mathrm{CuO}\right]^{+}+\mathrm{C}_{2} \mathrm{H}_{6} \rightarrow\left[\left(\mathrm{CH}_{3} \mathrm{CN}\right) \mathrm{Cu}(\mathrm{OH})\right]^{+}+\mathrm{C}_{2} \mathrm{H}_{5}{ }^{\circ}$

$\left[\left(\mathrm{CH}_{3} \mathrm{CN}\right) \mathrm{CuO}^{+}+\mathrm{C}_{2} \mathrm{H}_{6} \rightarrow\left[\left(\mathrm{CH}_{3} \mathrm{CN}\right) \mathrm{Cu}\right]^{+}+\mathrm{C}_{2} \mathrm{H}_{5} \mathrm{OH}\right.$

$\left[\left(\mathrm{CH}_{3} \mathrm{CN}\right) \mathrm{CuO}\right]^{+}+\mathrm{C}_{2} \mathrm{H}_{6} \rightarrow\left[\left(\mathrm{CH}_{3} \mathrm{CN}\right) \mathrm{Cu}\left(\mathrm{H}_{2} \mathrm{O}\right)\right]^{+}+\mathrm{C}_{2} \mathrm{H}_{4}$

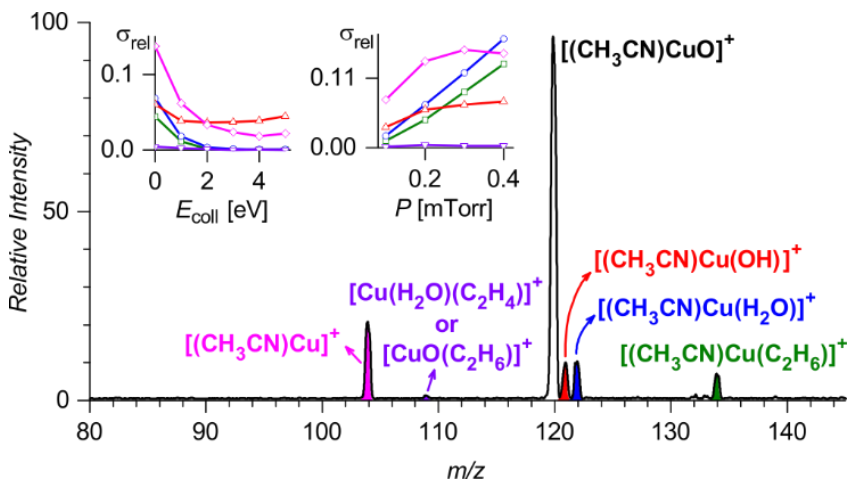

Figure 6. Reaction of mass-selected $\left[\left(\mathrm{CH}_{3} \mathrm{CN}\right) \mathrm{CuO}^{+}(\mathrm{m} / \mathrm{z} 120)\right.$ with $\mathrm{C}_{2} \mathrm{H}_{6}$ ( $E_{\text {coll }}$ $\left.=0 \mathrm{eV}, P\left(\mathrm{C}_{2} \mathrm{H}_{6}\right)=0.2 \mathrm{mTorr}\right)$. The insets show the pressure dependence ( $E_{\text {coll }}$ $=0 \mathrm{eV})$ and the collision energy dependence $\left(P\left(\mathrm{C}_{2} \mathrm{H}_{6}\right)=0.2 \mathrm{mTorr}\right)$ of the relative reaction cross sections (color-coded).

The collision energy and the pressure dependence of the double hydrogen abstraction channel show that it proceeds via a collisional complex (the insets in Figure 6). The relative cross section of this channel drops rapidly with the increasing collision energy. At the zero collision energy, the yield of dehydrogenation increases almost linearly with the $\mathrm{C}_{2} \mathrm{H}_{6}$ pressure. The $\left[\left(\mathrm{CH}_{3} \mathrm{CN}\right) \mathrm{Cu}\left(\mathrm{H}_{2} \mathrm{O}\right)\right]^{+}$product ion can also be formed as a secondary product in reaction of the $\left[\left(\mathrm{CH}_{3} \mathrm{CN}\right) \mathrm{Cu}\right]^{+}$ product ion with background water molecules (water can be present as a background gas in the collision cell). Such scenario was excluded by a labelling experiment. The reaction of ${ }^{18} \mathrm{O}$ labelled reactant ion $\left[\left(\mathrm{CH}_{3} \mathrm{CN}\right) \mathrm{Cu}^{18} \mathrm{O}\right]^{+}$with $\mathrm{C}_{2} \mathrm{H}_{6}$ leads to the corresponding $\left[\left(\mathrm{CH}_{3} \mathrm{CN}\right) \mathrm{Cu}\left(\mathrm{H}_{2}{ }^{18} \mathrm{O}\right)\right]^{+}$product ion (Figure $\mathrm{S} 7$ ). The secondary reaction would be expected to yield the $\left[\left(\mathrm{CH}_{3} \mathrm{CN}\right) \mathrm{Cu}\left(\mathrm{H}_{2}{ }^{16} \mathrm{O}\right)\right]^{+}$ion.

The single hydrogen abstraction channel has an interesting collision energy profile (red line in the left inset in Figure 6). The maximum cross section for the formation of $\left[\left(\mathrm{CH}_{3} \mathrm{CN}\right) \mathrm{Cu}(\mathrm{OH})\right]^{+}$ is at zero collision energy, but it does not decrease with the increasing collision energy as observed for all other reaction channels. After a somewhat decrease, the cross section starts to increase again with the increasing collision energy. It means that the reaction proceeds via a collisional complex at low collision energies like all other reaction channels. At larger collision energies, it can probably proceed as a direct $\mathrm{H}$-abstraction without the formation of a complex. On contrary, the subsequent reaction (rebound) step leading to ethanol and $\left[\left(\mathrm{CH}_{3} \mathrm{CN}\right) \mathrm{Cu}\right]^{+}$is effective only at about zero collision energy. At larger collision energies, the minor abundance of $\left[\left(\mathrm{CH}_{3} \mathrm{CN}\right) \mathrm{Cu}\right]^{+}$is due to collision induced dissociation of the parent ions (Figure S2b). The complexes with $P Q$ and phen ligands are less reactive. It was shown previously that $\left[(\right.$ phen $) \mathrm{CuO}^{+}$can activate propane and larger hydrocarbons (also: see Figure S6 for the reaction with 1,4-cyclohexadiene). ${ }^{[39]}$

2.3.3. Reaction with ethylene. Epoxidation of olefins is another typical reactivity of hypervalent metal-oxo complexes. ${ }^{[45,46]}$ Figure 7 shows that all of the studied complexes readily undergo oxygen transfer with ethylene (Reaction 7). All spectra show the formation of the oxygen transfer products $[(\mathrm{L}) \mathrm{Cu}]^{+}$(in red in Figure 7 and Figure S11) and their secondary adducts with 
ethylene $\left[(\mathrm{L}) \mathrm{Cu}\left(\mathrm{C}_{2} \mathrm{H}_{4}\right)\right]^{+}$(highlighted by green). Based on the mass of the detected products we cannot distinguish whether the oxygen-transfer products correspond to ethylene oxide or its more stable isomer acetaldehyde.

$[(\mathrm{L}) \mathrm{CuO}]^{+}+\mathrm{C}_{2} \mathrm{H}_{4} \rightarrow[(\mathrm{L}) \mathrm{Cu}]^{+}+\mathrm{C}_{2} \mathrm{H}_{4} \mathrm{O}$
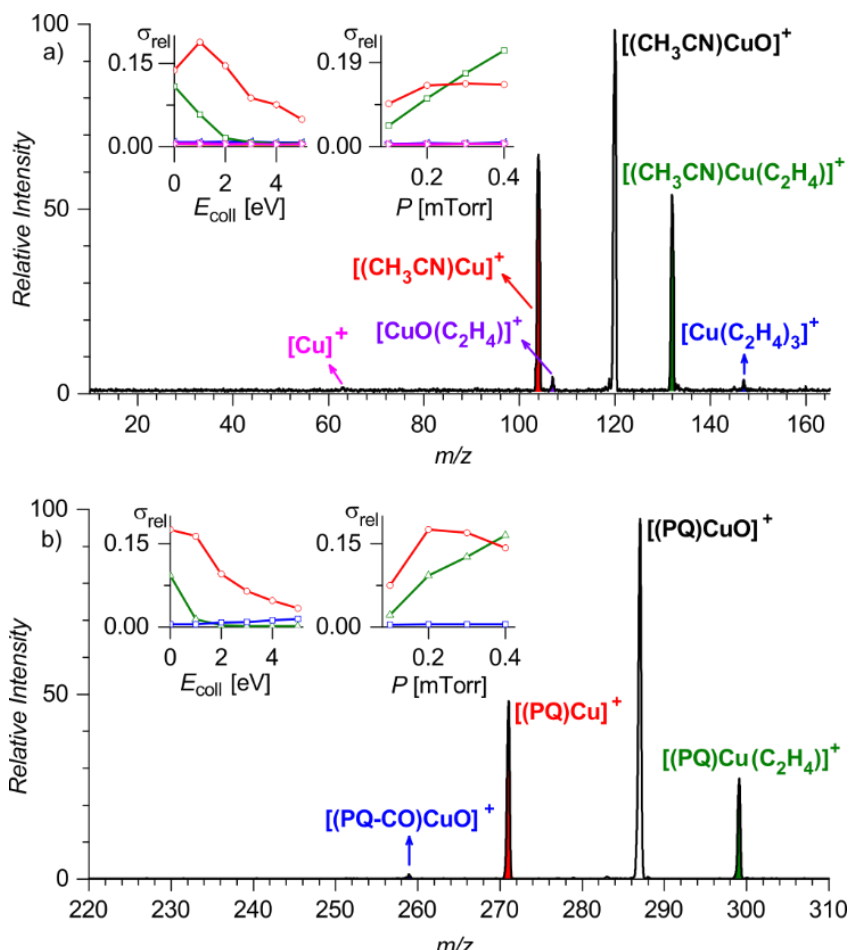

Figure 7. Reaction of mass-selected a) $\left[\left(\mathrm{CH}_{3} \mathrm{CN}\right) \mathrm{CuO}\right]^{+}(\mathrm{m} / z$ 120) and b) $\left[(\mathrm{PQ}) \mathrm{CuO}^{+}(\mathrm{m} / \mathrm{z} 287)\right.$ with $\mathrm{C}_{2} \mathrm{H}_{4}\left(E_{\text {coll }}=0 \mathrm{eV}, P\left(\mathrm{C}_{2} \mathrm{H}_{4}\right)=0.2 \mathrm{mTorr}\right)$. The insets show the pressure dependence $\left(E_{\text {coll }}=0 \mathrm{eV}\right)$ and the collision energy dependence $\left(P\left(\mathrm{C}_{2} \mathrm{H}_{6}\right)=0.2 \mathrm{mTorr}\right)$ of the relative reaction cross sections (color-coded).

2.3.4. Comparison of the reactivities. Finally, we have compared relative cross sections in all studied reactions obtained under the same conditions. The values in Table 1 represent sums of the relative cross sections of all channels corresponding to the oxygen transfer reactions to the substrate (OAT) or to the sum of OAT and HAT (hydrogen transfer) reactions (for all results see Table $\mathrm{S} 1$ ). The total relative cross sections in all reactions of $\left[\left(\mathrm{CH}_{3} \mathrm{CN}\right) \mathrm{CuO}\right]^{+}$are similar despite the fact that the reactions have distinctly different reaction pathways. It is consistent with a view that reactions proceed with the collision rate.

Table 1. Comparison of the total relative cross sections $\left(\sigma_{\text {rel }}\right)$ for oxygen atom transfer (OAT) and hydrogen atom transfer (HAT) reaction of copper(III)-oxo complexes with $\mathrm{H}_{2} \mathrm{O}, \mathrm{C}_{2} \mathrm{H}_{4}$, and $\mathrm{C}_{2} \mathrm{H}_{6}$. ${ }^{a}$

\begin{tabular}{lccc}
\hline Reactant & $\mathrm{H}_{2} \mathrm{O}$ & $\mathrm{C}_{2} \mathrm{H}_{4}$ & $\mathrm{C}_{2} \mathrm{H}_{6}$ \\
{$[(\mathrm{~L}) \mathrm{CuO}]^{+}$} & $\sigma_{\text {rel }}{ }^{\mathrm{a}}(\mathrm{OAT})$ & $\sigma_{\text {rel }}{ }^{\mathrm{a}}(\mathrm{OAT})$ & $\sigma_{\text {rel }}{ }^{\mathrm{a}}(\mathrm{HAT}+\mathrm{OAT})$ \\
\hline $\mathrm{L}=\mathrm{CH}_{3} \mathrm{CN}$ & $0.17 \pm 0.03$ & $0.24 \pm 0.10$ & $0.14 \pm 0.01$ \\
$\mathrm{~L}=\mathrm{PQ}$ & $<1 \times 10^{-3}$ & $0.23 \pm 0.05$ & $<2 \times 10^{-3}$ \\
$\mathrm{~L}=$ phen & $<2 \times 10^{-3}$ & {$[0.11]^{\mathrm{b}}$} & $<3 \times 10^{-3}$ \\
\hline
\end{tabular}

${ }^{a}$ Pressure of neutral reactants was 0.1 mTorr. Collision energy was $0 \mathrm{eV}$.

${ }^{\mathrm{b}}$ Note that mixture of $[(\text { phen }) \mathrm{CuO}]^{+}$and ions $\left[\left(\mathrm{phen}^{\mathrm{ox}}\right) \mathrm{Cu}\right]^{+}$was investigated.
Reactivities of the studied complexes in reactions involving hydrogen atom transfer as the first step (water oxidation and hydrocarbon hydroxylation) are significantly influenced by the ligand at the $\mathrm{Cu}-\mathrm{O}^{+}$moiety. As discussed above, the bidentate ligands switch off the water oxidation reaction and do not allow $\mathrm{C}-\mathrm{H}$ activation/hydroxylation of ethane (only larger hydrocarbons are activated). On the other hand, pure oxygen transfer in reaction with ethylene seems to be almost unaffected by the ligand. The complexes $\left[\left(\mathrm{CH}_{3} \mathrm{CN}\right) \mathrm{CuO}\right]^{+}$and $[(\mathrm{PQ}) \mathrm{CuO}]^{+}$display the same relative reaction cross sections within the experimental error. The reactivity of the $\left[(\right.$ phen $) \mathrm{CuO}^{+}$complex is seemingly smaller, but this is a consequence of the investigation of a mixture of $\left[(\right.$ phen $) \mathrm{CuO}^{+}$and unreactive $\left[\left(\text {phen }^{\mathrm{ox}}\right) \mathrm{CuO}\right]^{+}$. Hence, oxygen-transfer reaction probably proceeds for all complexes with efficiency close to the collision rate.

2.4. DFT calculations. We have investigated all reactions described above using DFT calculations. Potential energy surface for the reaction of $\left[\left(\mathrm{CH}_{3} \mathrm{CN}\right) \mathrm{CuO}\right]^{+}$with ethane is in the Supporting Information (Figure S22). The mechanism of this reaction is analogous to the previously published HAT and OAT mechanisms between metal-oxo complexes and hydrocarbons. ${ }^{[46,47]}$ We will discuss the reaction with water and ethylene in detail here.

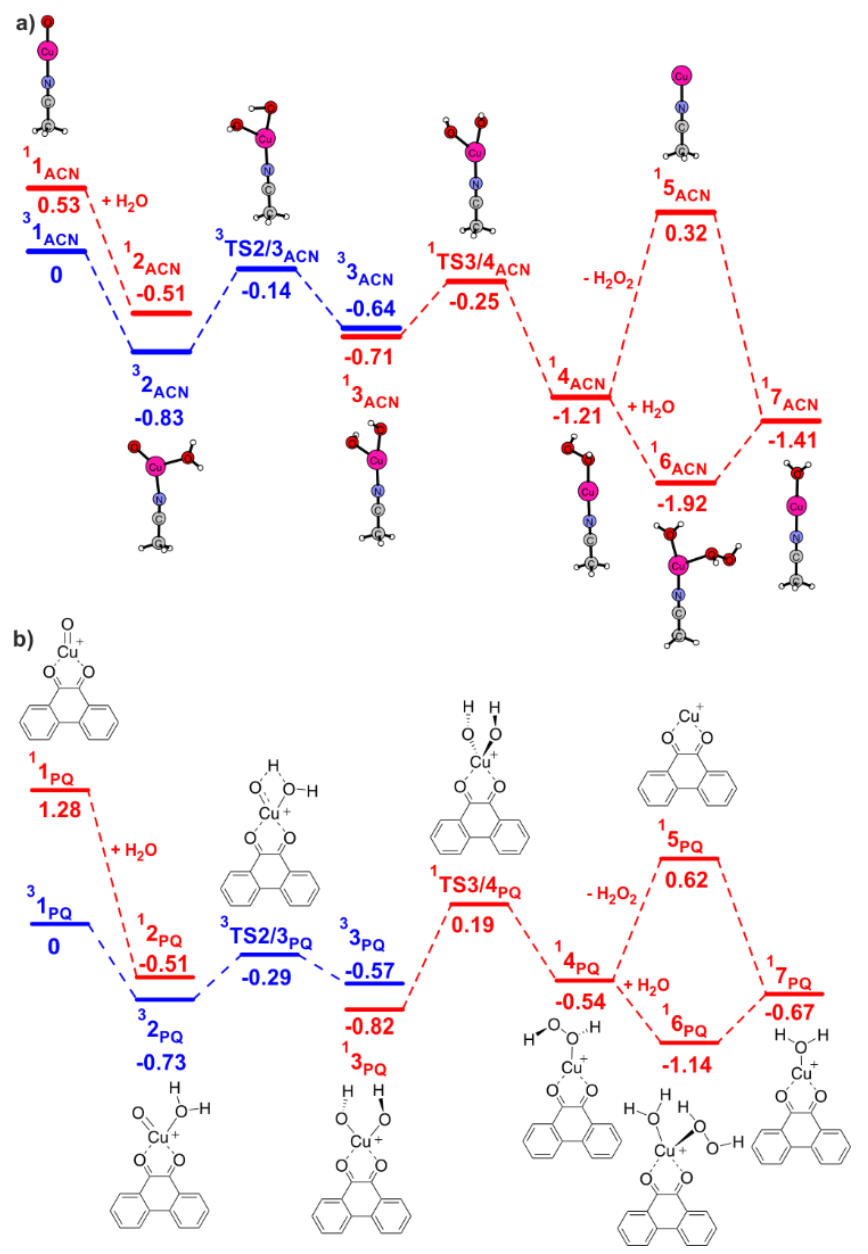

Figure 8. B3LYP-D3/6-311+G** potential energy surface for the reaction of a) $\left[\left(\mathrm{CH}_{3} \mathrm{CN}\right) \mathrm{CuO}\right]^{+}$and b) $[(\mathrm{PQ}) \mathrm{CuO}]^{+}$with water. The blue and red lines are for the triplet and singlet states, respectively. The relative energies are given in $\mathrm{eV}$ at $0 \mathrm{~K}$. 
Reaction of $\left[(\mathrm{L}) \mathrm{CuO}^{+}\left({ }^{3} \mathbf{1}_{\mathrm{L}}\right)\right.$ with water first proceeds on the triplet potential energy surface to the formation of adduct $\left[(\mathrm{L}) \mathrm{CuO}\left(\mathrm{H}_{2} \mathrm{O}\right)\right]^{+}\left({ }^{3} \mathbf{2} \mathrm{L}\right.$, Figure 8). This complex can undergo a reversible rearrangement (via transition structure ${ }^{3} \mathbf{T S} 2 / 3_{\mathrm{L}}$ ) to the dihydroxo intermediate $\left[(\mathrm{L}) \mathrm{Cu}(\mathrm{OH})_{2}\right]^{+}\left(\mathbf{3}_{\mathrm{L}}\right)$. This complex has a singlet ground state $\left({ }^{1}{ }^{3} \mathrm{~L}\right)$ and is very close in energy to the primary adduct ${ }^{3} \mathbf{2}$. . Reaction can further proceed on the singlet potential energy surface towards the coupling of two $\mathrm{OH}$ groups to form hydrogen peroxide. The energy barrier for this process $\left({ }^{1} \mathrm{TS} 3 / \mathbf{4}_{\llcorner}\right)$is below the energy of the initial reactants for the ${ }^{3} \mathbf{1}_{\mathrm{ACN}}$ complex, whereas it lies above the available energy for the ${ }^{3} \mathbf{1}_{\mathrm{PQ}}$ complex. This nicely explains why ${ }^{3} \mathbf{1}_{\mathrm{ACN}}$ oxidizes water, whereas ${ }^{3} 1_{\mathrm{PQ}}$ provides only oxygen exchange by reversible rearrangement of ${ }^{3} 2_{\mathrm{PQ}}$ to ${ }^{3} 3_{\mathrm{PQ}} /{ }^{1} \mathbf{3}_{\mathrm{PQ}}$. The final elimination of $\mathrm{H}_{2} \mathrm{O}_{2}$ from the ${ }^{1} \mathbf{4}_{\mathrm{ACN}}$ cation has to be assisted by another water molecule (Figure 8a).

A plausible explanation for the minor channel in the reaction between the ${ }^{3} \mathbf{1}_{\mathrm{ACN}}$ cation and water that leads to the bare copper ion can stem from the oxidation of the acetonitrile molecule. Upon coordination of water to the copper ion, the oxygen atom can insert into the copper-nitrogen bond. This highly exothermic process leads to $\left[\left(\mathrm{CH}_{3} \mathrm{CNO}\right) \mathrm{Cu}\left(\mathrm{H}_{2} \mathrm{O}\right)\right]^{+}$. Rearrangement of acetonitrile $\mathrm{N}$-oxide to methyl isocyanate $\left(\mathrm{CH}_{3} \mathrm{NCO}\right)$ and its subsequent hydration to methyl carbamic acid releases even more energy, which could probably explain the observation of bare and hydrated copper ions (for our exploratory calculations see Figure S21).

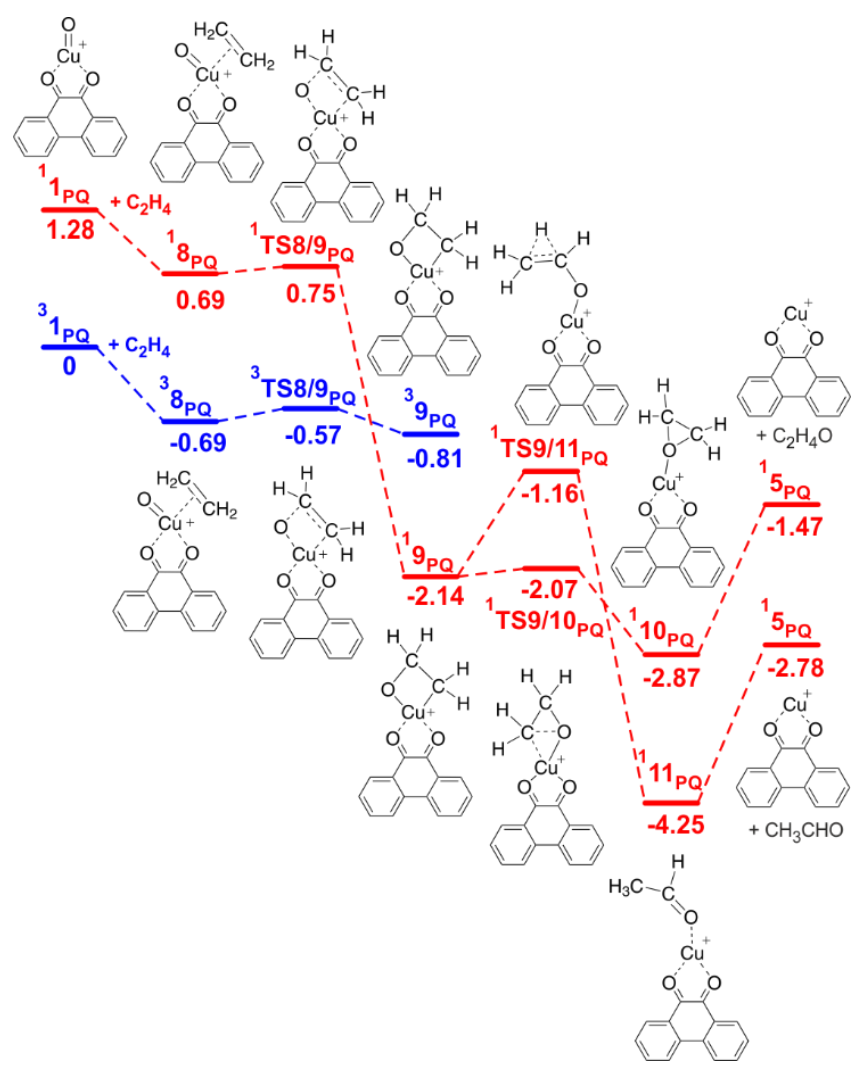

Figure 9. B3LYP-D3/6-311+G** potential energy surface for the reaction of $\left[(\mathrm{PQ}) \mathrm{CuO}^{+}\right.$with ethylene. The blue and red lines are for the triplet and singlet states, respectively. The relative energies are given in $\mathrm{eV}$ at $0 \mathrm{~K}$.
The reaction of $[(\mathrm{PQ}) \mathrm{CuO}]^{+}$with ethylene is to a certain degree similar to the previously published reaction of $\mathrm{Ag}_{2} \mathrm{O}^{+}$with ethylene (Figure 9). ${ }^{[4]}$ The reaction proceeds via an intermediate with a 4 -membered ring $\left({ }^{1} \boldsymbol{9}_{\mathrm{PQ}}\right)$. Its formation is associated with a spin crossover from the triplet PES to the singlet PES. This intermediate can rearrange to form either an ethylene oxide complex ${ }^{1} \mathbf{1 0}_{\mathrm{PQ}}$ or acetaldehyde complex ${ }^{1} \mathbf{1 1}_{\mathrm{PQ}}$. The epoxide product ${ }^{1} \mathbf{1 0}_{\mathrm{PQ}}$ is formed via a negligible energy barrier ( $\left.{ }^{1} \mathrm{TS} 9 / 10_{\mathrm{PQ}}\right)$, whereas the rearrangement to acetaldehyde requires energy of about $1 \mathrm{eV}\left({ }^{1} \mathrm{TS} 9 / \mathbf{1 1}_{\mathrm{PQ}}\right)$. The former process is therefore kinetically favoured. The acetaldehyde product is favoured thermodynamically. Energy barriers for both reaction pathways lie well below the energy of the reactants and therefore both can surmounted under the conditions of gas phase experiments.

\section{Conclusions}

We have shown that hypervalent copper(III)-oxo complexes can be easily formed in the gas phase from their copper(II) chlorate precursors. We demonstrated it by generation of a series of $[(\mathrm{L}) \mathrm{CuO}]^{+}$complexes with various monodentate and bidentate ligands $\mathrm{L}$. Further, we investigated reactivity of $[(\mathrm{L}) \mathrm{CuO}]^{+}\left(\mathrm{L}=\mathrm{CH}_{3} \mathrm{CN}, \mathrm{PQ}\right.$, phen $)$ with water and with saturated/unsaturated hydrocarbons. In reactions with water and alkanes, the complex with acetonitrile is more reactive than the complexes bearing bidentate ligands. We show that $\left[\left(\mathrm{CH}_{3} \mathrm{CN}\right) \mathrm{CuO}\right]^{+}$is capable of oxidizing water to hydrogen peroxide, whereas $\left[(\mathrm{PQ}) \mathrm{CuO}^{+}\right.$and $[(\text {phen }) \mathrm{CuO}]^{+}$provide only oxygen exchange reaction. The $\left[\left(\mathrm{CH}_{3} \mathrm{CN}\right) \mathrm{CuO}\right]^{+}$complex is capable of $\mathrm{C}-\mathrm{H}$ activation and hydroxylation of ethane. All complexes readily undergo oxygen transfer reactions with ethylene at comparable rates. All reaction mechanisms were investigated with DFT calculations. The results perfectly explain the observed reactivity trends.

\section{Experimental and Theoretical Details}

Mass Spectrometry. The experiments were performed with TSQ 7000 (Finnigan) equipped with an electrospray ionization (ESI) source. ${ }^{[48,49]}$ Solutions were introduced into the instrument via a fused-silica capillary at a rate of $1.5 \mu \mathrm{L} \mathrm{min}{ }^{-1}$. ESI parameters were: spray voltage $4 \mathrm{kV}$, sheath gas pressure 70 psi, no auxiliary gas, capillary voltage $0 \mathrm{~V}$, capillary temperature $150{ }^{\circ} \mathrm{C}$ and tube lens $140 \mathrm{~V}$. The $[(\mathrm{L}) \mathrm{CuO}]^{+}$cations were generated by electrospray ionization of a methanol solution containing a ligand ( $L=P Q$ or phen, $c=0.5 \mathrm{mM}$ ) and copper(II) chlorate $(\sim 0.3 \mathrm{mM}, \sim 0.3 \mathrm{M}$ stock solution was prepared by mixing $0.58 \mathrm{M}$ solution of $\mathrm{KClO}_{3}$ in water with 1 equivalent of $\mathrm{Cu}\left(\mathrm{ClO}_{4}\right)_{2} \cdot 6 \mathrm{H}_{2} \mathrm{O}$ and filtering out the precipitated $\left.\mathrm{KClO}_{4}\right)$. $\left[\left(\mathrm{CH}_{3} \mathrm{CN}\right) \mathrm{CuO}\right]^{+}$was generated similarly, but no ligand was added and acetonitrile was used as solvent. Preparation of other complexes $[(\mathrm{L}) \mathrm{CuO}]^{+}$is described in the Supporting Information.

TSQ 7000 has a quadrupole-octopole-quadrupole geometry allowing MS and MS/MS experiments (collision induced dissociation - CID - experiments and reactivity studies). For the MS/MS experiments, the reactant ions were mass-selected by the first quadrupole and guided through the octopole collision 
cell. The pressure of the gas in the collision cell was measured by a baratron. The collision energy was set by the potential offset between the octopole and the ion source. The offset corresponding to zero collision energy was determined by retarding potential analysis (in rough words we set the potential offset so that only one half of the parent ions can pass the octopole, see Figure S5). ${ }^{[50]}$ The reactant as well as the product ions were mass-analysed by the second quadrupole and detected by a Daly-type detector. The relative cross sections were obtained from the determined ion abundances $l_{\mathrm{i}}$ according to Equation 1, where $l_{i}$ is the abundance of the product ions $i$ and $l_{p}$ is the abundance of the parent ions (index $n$ is used, when a sum of abundances of all product ions $l_{i}$ is calculated).

$\sigma_{i}=-\ln \left(1-\Sigma I_{n} /\left(\Sigma I_{n}+I_{P}\right)\right) l_{i} / \Sigma I_{n}$

(Equation 1)

The relative cross sections in Figures 6, 7 and Figures S8-S18 in the Supporting Information are determined according to Equation 2.

$\sigma_{i}=l_{j}\left(\sum I_{n}+I_{P}\right)$

(Equation 2)

IRMPD spectroscopy. The experiments were performed with a Bruker Esquire 3000 ion trap mass spectrometer mounted to a CLIO (Centre Laser Infrarouge Orsay) free electron laser (FEL). Detailed description of this apparatus is available elsewhere. ${ }^{[51]}$ We used the same approach to prepare the solutions for the IRMPD measurement as mentioned above. The $[(\mathrm{PQ}) \mathrm{CuO}]^{+}$ions were generated by ESI, mass selected and stored within the ion trap, where they were irradiated with infrared light. The FEL was operated at $44 \mathrm{MeV}$ electron energy, which provided light in the $900-1800 \mathrm{~cm}^{-1}$ range. Spectral resolution was $15-20 \mathrm{~cm}^{-1}$ (full width at half-maximum, fwhm). ${ }^{[52,53]}$ The dominant photofragmentation was the loss of the oxygen atom. The IRMPD spectrum (Figure 3a) was obtained as a dependence of the fragmentation abundance on the IR photon energy.

DFT Calculations. All calculations were performed with density functional theory method B3LYP ${ }^{[54-57]}$ with D3 empirical correction for dispersion interactions ${ }^{[58]}$ as implemented in the Gaussian 09 package. ${ }^{[59]}$ The geometries were first optimized with the $6-31 \mathrm{G}^{*}$ basis set and then re-optimized with the 6$311+G^{* *}$ basis set. At both levels, frequency calculations were performed to characterize the minima/transition states and to obtain theoretical IR spectra for comparison with the experimental data. The B3LYP-D3/6-311+G** IR spectra are scaled by $0.986 .{ }^{[60]}$ The transition state structures were further characterized by intrinsic reaction coordinate calculations. ${ }^{[1]}$ The relative energies are given in $\mathrm{eV}$ at $0 \mathrm{~K}$. Optimized geometries are given in a separate $X Y Z$ Supporting Information file (the structures can be visualized by standard visualization programs).

\section{Acknowledgements}

This research was supported by the European Research Council (CoG IsoMS, No. 682275) and the Czech Science Foundation (14-20077S). The results from the CLIO were obtained owing to the founding from the European Union's Seventh Framework Programme (FP7/2007-2013) under the grant agreement No.
226716. The CLIO staff, particularly Vincent Steinmetz, is acknowledged for their help and assistance.

Keywords: Gas phase reactivity $\cdot \mathrm{C}-\mathrm{H}$ activation $\cdot$ Copper complexes $\cdot$ Infrared spectroscopy $\bullet$ Oxygen transfer

[1] A. G. Blackmann, W. B. Tollman in Structure and Bonding, Vol. 197 (Ed.: B. Meunier), Springer, Berlin, 2000, pp. 179-212.

[2] K. Ray, F. F. Pfaff, B. Wang, W. Nam, J. Am. Chem. Soc. 2014, 136, 13942-13958.

[3] W. Nam, Acc. Chem. Res. 2015, 48, 2415-2423.

[4] M. Puri, L. Que, Jr., Acc. Chem. Res. 2015, 48, 2443-2452.

[5] A. S. Borovik, Chem. Soc. Rev. 2011, 40, 1870-1874.

[6] A. Gunay, K. H. Theopold, Chem. Rev. 2010, 110, 1060-1081.

[7] R. H. Holm, Chem. Rev. 1987, 87, 1401-1449.

[8] S. M. Barnett, K. I. Goldberg, J. M. Mayer, Nat. Chem. 2012, 4, 498-502.

[9] M. D. Kärkäs, O. Verho, E. V. Johnston, B. Åkermark, Chem. Rev. 2014, 114, 11863-12001.

[10] A. Singh, L. Spiccia, Coord. Chem. Rev. 2013, 257, 2607-2622.

[11] J. D. Blakemore, R. H. Crabtree, G. W. Brudvig, Chem. Rev. 2015, 115, 12974-13005 and references therein.

[12] E. M. Duffy, B. M. Marsh, J. M. Voss, E. Garand, Angew. Chem. Int. Ed. 2016, 55, 4079-4082.

[13] T. A. Betley, Qin Wu, T. Van Voorhis, D. G. Nocera, Inorg. Chem. 2008 $47,1849-1861$.

[14] J. Roithová, D. Schröder, Chem. Rev. 2010, 110, 1170-1211.

[15] H. Schwarz, Angew. Chem. Int. Ed. 2011, 50, 10096-10115.

[16] K. B. Cho, H. Hirao, S. Shaik, W. Nam, Chem. Soc. Rev. 2016, 45, 1197-1210.

[17] E. Rezabal, J. Gauss, J. M. Matxain, R. Berger, M. Diefenbach, M. C. Holthausen, J. Chem. Phys. 2011, 134, 064304.

[18] E. R. Fisher, J. L. Elkind, D. E. Clemmer, R. Georgiadis, S. K. Loh, N. Aristov, L. S. Sunderlin, P. B. Armentrout, J. Chem. Phys. 1990, 93, 2676 - 2691.

[19] M. T. Rodgers, B. Walker, P.B. Armentrout, International Journal of Mass Spectrometry 1999, 182/183, 99-120.

[20] N. Dietl, Ch. van der Linde, M. Schlangen, M. K. Beyer, H. Schwarz, Angew. Chem., Int. Ed. 2011, 50, 4966-4969.

[21] E. I. Solomon, D. E. Heppner, E. M. Johnston, J. W. Ginsbach, J. Cirera, M. Qayyum, M. T. Kieber-Emmons, C. H. Kjaergaard, R. G. Hadt, L. Tian, Chem. Rev. 2014, 114, 3659-3853.

[22] S. Sirajuddin, A. C. Rosenzweig, Biochemistry 2015, 54, 2283-2294.

[23] R. A. Himes, K. D. Karlin, Curr. Op. Chem. Biol. 2009, 13, 119-131.

[24] A. Casitas, X. Ribas, Chem. Sci. 2013, 4, 2301-2318.

[25] F. C. Anson, T. J. Collins, T. G. Richmond, B. D. Santarsiero, J. E. Toth, B. G. R. T. Treco, J. Am. Chem. Soc. 1987, 109, 2974-2919.

[26] J. Hanss, H. J Krüger, Angew. Chem. 1996, 35, 2827-2830.

[27] I. H. Wasbotten, T. Wondimagegn, A. Ghosh, J. Am. Chem. Soc. 2002 124, 8104-8116.

[28] K. L. Vikse, P. Chen, Organometallics 2015, 34, 1294-1300.

[29] E. A. King, L. M. Huffman, A. Casitas, M. Costas, X. Ribas, S. S. Stahl, J. Am. Chem. Soc. 2010, 132, 12068-12073.

[30] L. M. Huffman, S. S. Stahl, J. Am. Chem. Soc. 2008, 130, 9196-9197.

[31] A. Putau, H. Brand, K. Koszinowski, J. Am. Chem. Soc. 2012, 134, 613622.

[32] M. Neumeier, R. M. Gschwind, J. Am. Chem. Soc. 2014, 136, 57655772 .

[33] N. Gagnon, W. B. Tolman, Acc. Chem. Res. 2015, 48, 2126-2131.

[34] P. J. Donoghue, J. Tehranchi, C. J. Cramer, R. Sarangi, E. I. Solomon, W. B. Tolman, J. Am. Chem. Soc. 2011, 133, 17602-17605.

[35] J. B. Gary, C. Citek, T. A. Brown, R. N. Zare, E. C. Wasinger, T. D. P. Stack, J. Am. Chem. Soc. 2016, 138, 9986-9995.

[36] E. A. Lewis, W. B. Tolman, Chem. Rev. 2004, 104, 1047-1076.

[37] L. M. Mirica, X. Ottenwaelder, T. D. P. Stack, Chem. Rev. 2004, 104, 1013-1045.

[38] L. Que, Jr., W. B. Tolman, Angew. Chem. Int. Ed. 2002, 41, 1114-1137.

[39] D. Schröder, M. C. Holthausen, H. Schwarz, J. Phys. Chem. B 2004 108, 14407-14416.

[40] L. Jašíková, E. Hanikýřová, D. Schröder, J. Roithová, J. Mass. Spectrom. 2012, 47, 460-465.

[41] N. J. Rijs, P. Gonzalez-Navarrete, M. Schlangen, H. Schwarz, J. Am. Chem. Soc. 2016, 138, 3125-3135.

[42] L, MacAleese, P. Maître, Mass Spectrom. Rev. 2007, 26, 583-605.

[43] N. C. Polfer, Chem. Soc. Rev. 2011, 40, 2211-2221.

[44] J. Roithová, Chem. Soc. Rev. 2012, 41, 547-559.

[45] K. A. Jorgensen, Chem. Rev. 1989, 89, 431-458. 
[46] J. Roithová, D. Schröder, J. Am. Chem. Soc. 2007, 129, 15311-15318.

[47] N. J. Rijs, T. Weiske, M. Schlangen, H. Schwarz, Chem. Phys. Lett. 2014, 608, 408-424.

[48] L. Ducháčková, J. Roithová, Chem. Eur. J. 2009, 15, 13399-13405.

[49] L. Jašíková, M. Anania, S. Hybelbauerová, J. Roithová, J. Am. Chem Soc. 2015, 137, 13647-13657.

[50] Z. Herman, Int. Rev. Phys. Chem. 1996, 15, 299-324.

[51] J. M. Ortega, F. Glotin, R. Prazeres, Infrared Phys. Technol. 2006, 49 133-138.

[52] L. Mac-Aleese, A. Simon, T. B. McMahon, J.M. Ortega, D. Scuderi, J. Lemaire, P. Maître, Int. J. Mass Spectrom. 2006, 14, 249-250.

[53] B. Paizs, B. J. Bythell, P. Maître, J. Am. Soc. Mass Spectrom., 2012, 23 664-675.

[54] S. H. Vosko, L. Wilk, M. Nusair, Can. J. Phys. 1980, 58, 1200-1211.

[55] C. Lee, W. Yang, R. G. Parr, Phys. Rev. B 1988, 37, 785-789.

[56] A. D. Becke, J. Chem. Phys. 1993, 98, 5648-5652.

[57] P. J. Stephens, F. J. Devlin, C. F. Chabalowski, M. J. Frisch, J. Phys Chem. 1994, 98, 11623-11627.

[58] S. Grimme, J. Antony, S. Ehrlich, H. Krieg, J. Chem. Phys. 2010, 132 154104.

[59] M. J. Frisch, et al. Gaussian 09, Revision A.02; Gaussian, Inc. Wallingford, CT, 2009

[60] A. P. Scott, L. Radom, J. Phys. Chem. 1996, 100, 16502-16513.

[61] K. Fuku, Acc. Chem. Res. 1981, 14, 363-368. 


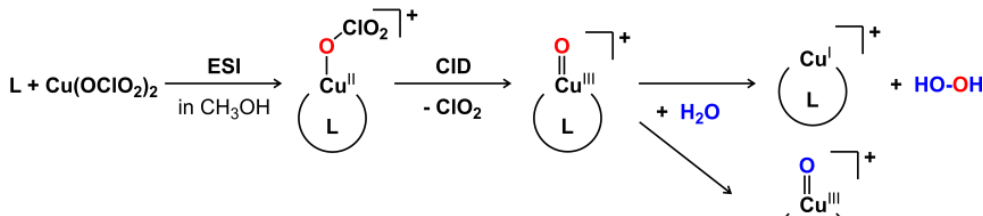

$$
\begin{aligned}
& \mathrm{L}=\text { acetonitrile, acetone, methanol, phenanthraquinone, phenanthroline } \\
& \left(\begin{array}{c}
\mathrm{Cu}^{\prime \prime \prime} \\
\mathrm{L}
\end{array}\right)+\mathrm{H}_{2} \mathrm{O}
\end{aligned}
$$

Electrospray ionization of copper chlorate salts is an efficient way to generate variety of $[(\mathrm{L}) \mathrm{CuO}]^{+}$complexes with monodentate or bidentate ligands $\mathrm{L}$. We show that the $[(\text { acetonitrile }) \mathrm{CuO}]^{+}$complex can oxidize water. Further, we show that oxygen transfer reactions are less influenced by the nature of the ligand $L$ than the hydrogen transfer reactions.
Ghazaleh Yassaghi, Erik Andris, Rafael Navrátil, Juraj Jašík, and Jana Roithová*

\section{Page 1-Page 8}

Reactivity of copper(III)-oxo complexes in the gas phase 